\title{
Morality in Competition Law: The Culture of Honesty and Trust in Consumer Protection
}

\author{
By Talya Ucaryilmaz
}

\begin{abstract}
Recent works in legal scholarship have shifted the focus of competition law to the economic analysis of law. Yet today we face the revival of the fairness concerns in competition polices. This article concerns itself with the nature of the interdependent relationship between competition law and consumer protection law as ancillary to the necessary relationship between law and morality. Hereby it aims to revisit their raison d'être to discuss that fairness and equity do not lack economic foundations. For an efficient market structure, private property and good faith in contractual relations are essential. This article aims to scrutinise the latter, while showing its objective criteria: Honesty, trust and reasonableness, as the moral essence of competition and consumer protection laws. These criteria provide efficient means to address moral aspects of fairness in competition law as it is best illustrated within its relation to consumer protection without compromising their economic foundations.
\end{abstract}

Keywords: competition law, consumer protection, fairness, good faith, honesty, trust

\section{Introduction}

Many scholarly works have already examined the co-existing relationship between competition policy and consumer protection within the discourse of neoclassical economics. Competition law is remarkably different from the consumer law. While the former refers to the body of regulatory initiatives aiming to promote efficient competition, the latter refers to the rules directed to protect the interests of the consumers as a special group of market actors. Competition law is directed to secure the competition in the market as a whole and hence, is not classspecific. As such, it may create negative effects for the consumers in the short run. Harm to consumers and harm to competition is not always equal. However since 1980s, the goals of competition law started to be linked with the consumer welfare standard. Consumer protection began to be referred as the fundamental objective of competition law. ${ }^{1}$ This article aims at dwelling into the nature of this existing relationship, rather than challenging this idea or scrutinising its contemporary manifestations. It argues that the relationship between competition policy and

\footnotetext{
*LL.M.; Ph.D.; Visiting Post-doctoral Fellow at the Amsterdam Centre for Transformative Private Law (UvA-ACT), UvA, Researcher at the Bilkent University Faculty of Law. The author thanks Professor Chantal Mak (University of Amsterdam) for her valuable comments. E-mail: talya@bilkent.edu.tr.

${ }^{1}$ NCAs Opinion of Advocate General Kokott delivered on 19 February 2009 in Case C-8/08 (2009) ECR I-4529, p. 85, Cseres (2013) at 9. Also see T-Mobile Netherlands and Others, Case C-8/08, (2009) ECR 0000.
} 
consumer protection is also a question of morality, as well as being a question of law and economics.

Law and economics scholarship suggests that the interdependent relationship between these two normative rule systems is based on their effects on the market. Competition and consumer protection laws both exist because of the market failures. While anti-competitive practices distort the supply side of the market, deceptive practices to the detriment of the consumers distort the demand side. ${ }^{2}$ If the temporal considerations are set aside, consumer protection and competition policies do not demonstrate a friction in the legal system. They are directed to the efficient allocation of the resources, increase of production and innovation. Competition law aims at increasing social welfare as a whole, and this also applies to consumer welfare as its extension. However from a historical perspective, one basic foundation on which they are built on is usually forgotten by the economists and legal scholars. They are oriented to correct the market failures and whereby to do it, they protect honesty and trust in the contractual relationships.

This article argues that honesty and trust are the moral basis of competition law as well as being the tokens which tie the competition policy to the consumer protection. This requires considering the society as a whole, simultaneously an object and a subject in the market and addressing the fairness problems from a perspective of a holistic notion of social justice. Seeing competition and consumer protection laws as agents of social justice, requires to re-calibrate the place of moral values for a stronger market order. Honesty and trust as moral values are transmitted into the legal realm via general principles such as good faith (bona fides) and the prohibition of the abuse of rights as its application. Such rules of conduct carry a core role in consumer-related contracts as the direct reflections of the fairness and social justice concerns. 3 Understanding the hermeneutic frame of bona fides and its fertility gives us freedom to understand not only the pivotal role of distributive concerns within the dynamics of competition law and consumer protection but also within the European legal culture as a whole. ${ }^{4}$ As such the article approaches the problem of social justice from its multipolarity: The economic, moral and historical foundations of competition and consumer protection as different yet parallel examples of market fairness.

One question needed to be addressed is the definition of morality and its role in safeguarding social justice. The murky terrain of morality and social justice results with the plurality of the opinions. Friedrich Hayek famously criticises the concept of social justice and its perception as a moral virtue, which eventually leads to self-contradiction. This article takes social justice not as virtue but as the legal standards whereby the distribution of power is regulated. While acknowledging the role of the external drives in guiding the conducts of the market actors, it discusses the role of the rules of conduct and their underlying moral values. ${ }^{5}$ For the purpose of this article, the concept of social justice refers to the system of legal standards that guarantee the equality of opportunity in the

\footnotetext{
${ }^{2}$ Leary (2005) at 1147-1148.

${ }^{3}$ Study Group of Social Justice of European Private Law (2004) at 664.

${ }^{4} \mathrm{Mak}(2012)$ at 331-332.

${ }^{5}$ Hayek (1978).
} 
distribution of power in the market, whereas fairness and distributive justice are taken as its ancillary.

As such, the article adopts a definition of morality to fit the target of moral theorising: Concretising the necessary relationship between law and morality as illustrated by the competition law and consumer protection. Morality in a descriptive sense refers to the normative social conduct rules, put forward by a society/a group of individuals, sustained by moral sanctions by that particular society or group. In other words, the article takes morality in a descriptive sense, as what is morally accepted in the society rather than its normative understanding that focuses on what is good or bad. ${ }^{6}$ It is beyond the scope of this article to explore the extent of divergent views on the relationship between law and morality. Law serves to the binary code of legal and illegal but the limits of morality is more blurry. Yet, the article is based on the premise that law and morality have contextually different yet common cores even though they differ from the perspective of institutional recognition. ${ }^{7}$

It is also nearly impossible to suggest a satisfactory legal definition for the moral values like honesty and trust. For this reason, this paper uses the Roman concept of bona fides: good faith as a behavioural standard that catches their meaning best holistically and universally. Roman legal tradition sets forth the criteria of bona fides as honesty, loyalty and reasonableness in contractual relationships between rivals. While loyalty refers to the trust on the efficient fulfilment of the promises, honesty and reasonableness together relate to the justice problem as they address the information asymmetry and the disclosure of efficient information between parties. This requires to adopt an Aristotelian idea of justice that revolved around proportionality and balance. The Aristotelian idea of 'just as proportional' and its transformative effect in European legal history helps us creating a link between the balance of interests and the contemporary understanding of equity. ${ }^{8}$ Commutative (or rectifying - in Latin rectum) justice referring to the idea of 'correction' in private exchanges is derived from distributive justice as social justice. As such the three components of bona fides touch upon the problematique of distributive and commutative justice altogether.

Comparative studies are essential in the legal analysis of the interdependent relationship between consumer protection and competition policy. Hereby, the reference to bona fides is used to show how honesty and trust as moral values are translated into the legal practical sphere. Legal history is one way of showing that legal systems and legal disciplines differ, yet they share substantial motives. Choosing a common terminology is also useful for demonstrating the symbiotic relationship with law and language. From a Derridean sense, language is the means by which law is created and transmitted to today's world. Therefore, bona fides should not be understood as a homogeneous legal tool but rather, a fertile source of values that should be contemplated while addressing the fairness and

\footnotetext{
${ }^{6}$ Durkheim (1973) at 63.

${ }^{7}$ Honoré (2002) at 491; Hart (1994) at 268.

${ }^{8}$ See Aristotle, Book X, Chapter 3, sec. 1; Book V, Chapter 3, sec. 2; Book V, Chapter 4, sec. 1; Book V, Chapter 5, sec. 1-3; Book V, Chapter 6, sec. 1-2.
} 
social justice concerns through the topography of competition and consumer protection laws.

\section{The Culture of Honesty and Trust}

The era of circular economy and sustainability started to remind us the moral concerns that are once pushed to periphery. Since last five years we witness the change in the competition and consumer protection narrative for the sake of fairness, especially by the Commissioner Vestager in the EU level. ${ }^{9}$ The fairness concerns in the contemporary market order are usually addressed by the distributive effects. As such, we witness the significantly increasing role of general principles of private law like bona fides whereby they shape the power dynamics both in the supply or demand side in today's neo-classical market. ${ }^{10}$ The reflections of social justice in European legal culture are essentially visible in the establishment of the economic order as they constantly shape each other. This makes the economic justice a concomitant of social justice as best illustrated in the relationship between competition and consumer protection.

Although having different histories and patterns, competition and consumer protection policies are essential in today's economic paradigm. They protect the free market economy from artificial constraints created by the individuals or collective bodies, and ideally they work in harmony. Their shared aim of increasing the consumer welfare, although with different methodologies and in different scales, make them relevant for social justice concerns. ${ }^{11}$ They are also closely linked to market morality, shaped around the culture of trust as the loyalty to the market and market actors, and honesty as the disclosure of essential information to prevent misperceptions.

The European legal culture dates back to classical Roman law of contracts and its legal remedies, especially bona fides as the ethical safeguard of the 'market'. In the classical era, the price in a sales contract did not need to be just; on the contrary rivalry was encouraged. However deceit (dolus) was prohibited by procedural mechanisms of case law mainly through the applications of the behavioural standard of bona fides and exceptio doli (exception of deceit). ${ }^{12}$ The idea behind was providing praetorian equity which was rooted in the Greek concept of epieikeia. ${ }^{13}$ As opposed to the antiquities, the early modern commercial world in Europe was shaped by the Christian natural law doctrine of market justice. Yet with the integration of classical remedies to 17 th century commercial

\footnotetext{
${ }^{9}$ Vestager M, Competition is a Consumer Issue, BEUC General Assembly, 13 May 2016, Working together for a Fair Competition Worldwide, UCL Jevons Institute Conference, 3 June 2016, Competition for a Fairer Society, 10th Annual Global Antitrust Enforcement Symposium, Georgetown, 20 September 2016, Protecting Consumers from Explotation, Chillin' Competition Conference, Brussels, 21 November 2016. For the texts https://ec.europa.eu/competition/speeches/ index_2016.html

${ }^{10}$ Study Group of Social Justice of European Private Law (2004) at 664.

${ }^{11}$ Cseres (2013) at 15, Cseres (2011) at 205-238.

${ }^{12}$ Ucaryilmaz (2020) at 43-59; Winkel (2010) at 155-156.

${ }^{13}$ Chroust (1942) at 124.
} 
practice the European commercial culture was formed around the idea of freedom: The free determination of price while safeguarding honesty and trust in contractual relations. The European legal culture as shared economic and legal knowledge is the result of social and economic interactions taking place since antiquities. This Weberian narrative reminds us that seeing law as a temporal/historical constant is over-simplification. When it comes to analyse the paradigms that experience dramatic shifts, we encounter that they are not that dramatic after all.

Law and economics scholarship is focused on the concept of efficiency as the normative goal of law. Recent works explain the focus of competition law and consumer protection with the economic analysis of law, sometimes forgetting their habitus: European legal culture. However today we face the revival of the fairness and moral concerns in competition policies. This creates the need to reconcile different approaches, or rather puts us into the difficult terrain of metainterdisciplinarity. Professor Ugo Mattei regularly emphasises that as historical and comparative evidence show, efficiency and equity are closely linked. ${ }^{14}$ Efficiency is doomed to lose its scientific rigour and objectivity when it enters the social realm of law. In the final analysis, they are both doctrinal techniques that should be considered in relation to the theory of legal transplants. ${ }^{15}$ Therefore the basic moral concepts that are embedded in western legal culture are key in this discussion.

The European legal tradition understands honesty as an objectified moral value that is translated into the legal realm as the disclosure of the necessary information to the other parties of the contractual relationship that might otherwise harm them. On the other hand trust indicates the environment of legal and moral security that protects the reliance on the promises. It is never considered as altruism, rather it refers to securing the legitimate interests that are worth being protected. Together with reasonableness, they are essential components of the objective good faith principle and the safeguard of social justice in contractual relations. Hereby, the Roman roots of competition law and consumer protection become a potentially valuable illustration of how to understand fairness in contract law, while not compromising the motivation of profit-seeking. This does not undermine the obvious fact that law is more complex in today's social-political ecology than in the past. Rather dwelling on its roots aims to emphasise the common core of the cosmopolitan nature of today's law.

Competition law and consumer protection law intersects at certain concerns such as the increase of consumer welfare in the long run, yet they are different in their basic enforcement methods or primary target group. However, there is a common moral basis they share: They protect honesty and trust in the market. Without considering its historical relationship with contractual morality, many scholars accept the ultimate role of truthfulness in competition law from an economic perspective. As Muris says, 'competition motivates sellers to provide truthful information about their products and drives them to fulfil their promises to consumers'. ${ }^{16}$ The consumer misperception results with inefficient competition.

\footnotetext{
${ }^{14}$ Mattei (1994) at 157.

${ }^{15}$ Mattei (1994) at 158.

${ }^{16}$ Muris (2005) at 168.
} 
The sellers are motivated by profit-maximisation, as the benefits they gain from the consumers which is translated in price. From a demand perspective, competition can only be efficient when the consumers accurately perceive their net benefit in both price and non-price terms. ${ }^{17}$ What would reduce the consumer misperception is to increase seller's incentives to correct the misperception. Legal norms that are based on honesty and trust as moral values correct such market failures. Commercial morality requires the contract not to be a source of unfair profit. Historically this view of equity which owes its existence to Greek epieikeia was provided through bona fides that protect honesty, loyalty and reasonableness. As an objective rule of conduct it was seen as the conceptual antonym of dolus (deceit). ${ }^{18}$ It is today an essential component of the European legal identity and central for regulating and de-regulating the contemporary market society.

The references to legal history are crucial as they constitute European legal culture and set forth the core principles of European legal order applicable to private relations. ${ }^{19}$ Such cosmopolitan view of private law is not limited to the Continental Europe. Although Anglo-American legal tradition is dramatically different than the civilian tradition in terms of legal history, methodology, and governance patterns, they share a common fairness discourse that sits in the middle of competition and consumer protection policies. The general rules of conduct which directly derive from the moral realm and later adopted by the legal instruments juxtapose the Continental contractual morality to Anglo-American concept of equity. They give the judiciary the necessary legitimacy to provide case-based legal solutions that is already intrinsic to the Anglo-American tradition. ${ }^{20}$ The equitable remedies in Anglo-American tradition owe their ultimate victory to their more efficient legal organisation. ${ }^{21}$ General principles like good faith that once belonged to the moral realm in Continental tradition also provide such efficiency in their flexible application. Competition and consumer protection laws, as established examples, internalise these moral principles and apply it to contemporary market concerns.

Not oddly, the idea of codification the competition rules first emerged in the US with the Sherman Act of 1890 where good faith had almost no practical role in the contractual relationships. However today the concerns of fairness, honesty and trust gained a central role in imposing control measures in Anglo-American competition laws to protect consumers. ${ }^{22}$ For example the American federal trade regulation focuses on the objective truthfulness or the 'honesty in fact' as one of its major considerations and evaluate the fraudulent behaviour of the market actors from a perspective of consumer protection. ${ }^{23}$ On the other hand the Competition law in Europe has been demonstrating a more interventionist approach, since it has weaker trust to the market forces compared to the US and a deeper tradition to

\footnotetext{
${ }^{17}$ Bar-Gill (2011) at 13, 35 .

${ }^{18}$ Whittaker (2019) at 409.

${ }^{19}$ Collins (2012).

${ }^{20} \mathrm{Mak}(2007)$ at 69.

${ }^{21}$ Mattei (1994).

${ }^{22}$ Whittaker (2019) at 439.

${ }^{23}$ Alexander (1962) at 141.
} 
protect market morality as a result of 2500 years of experience ${ }^{24}$ The Continental practice demonstrate the interdependent relationship between competition and consumer protection from the perspective of their shared 'goal' for which values play an essential role, whereas the Anglo-American tradition adopts a more resultoriented approach. ${ }^{25}$ In any case, the protection of honesty and trust intersects on their shared perspective on rivalry and freedom in liberal commercial life. For the competition to persist in the long run, honesty and trust between rivals oil the wheels of the market economy.

\section{Efficiency and Morality}

Honesty, loyalty and trust are integrated in the European commercial culture since antiquity. ${ }^{26}$ Being intrinsically moral concepts, they do not lack economic foundations. Institutional economics explains 'trust' as the antonym of opportunism in relation to honesty. According to Williamson opportunism is the lack of honesty in commercial transactions. In other words, opportunism is often paired with strategic dishonesty guided by egoistic motives. It is the economic reflection of the Roman dolus as it refers to withholding or distorting information to mislead and deceive other actors. In a contractual setting, opportunism signifies dishonest and disloyal behaviour that is against the other party's reasonable expectations based on their agreement, previous conduct or conventional morality. ${ }^{27}$ Williamson's transaction cost economics takes the economic interaction as a contractual problem. ${ }^{28}$ In this puzzle abstaining from opportunistic conduct is a requirement of efficient market exchanges and the moral standard of general principles are wellequipped whereby to provide this. Competition law and consumer law together protect the honest sellers from the costs of over-investing for the extra-ordinary measures to create the minimum level of trust.

According to Summers, bona fides is an exclusionary concept. ${ }^{29}$ It excludes a heterogeneous set of mala fide behaviours. The idea of the prohibition of the mala fide behaviours such as dishonesty and furtive behaviour of the competitive actors makes business ethics vital in competition and consumer protection. Efficiency as a standard of legal scholarship is seen as a peculiarity of the American system as a result of the works of Demsetz, Posner and other members of the Chicago School starting from 1970s but efficiency as a way of reasoning comes from the Continental legal history. Equity requires the social loss to be minimised, accompanied by the meta-standard of reasonableness. ${ }^{30}$ The social aspect of competition law shows itself in its idea of protecting the consumers as an independent yet, retrospectively structured aim. In other words, competition law

\footnotetext{
${ }^{24}$ Leary (2005) at 1147.

${ }^{25}$ Leary (2005) at 1147.

${ }^{26}$ Schiller (1930) at 845,

${ }^{27}$ Cohen (1992) at 957.

${ }^{28}$ Williamson (1975) at 25, Williamson (1985) at 47.

${ }^{29}$ Summers (1982), the Ghosh test in English law also requires honesty to be determined by the meta-standard of reasonableness. MacCulloch (2007) at 357.

${ }^{30}$ Mattei (1994).
} 
protects the consumers with instrumental motives. Long term efficiency goals are the main reason why competition authorities, policy makers and politicians regularly place the consumers at the centre of their competition policy. Competition and consumer protection have a symbiotic, organic and living relationship that determines the development of law as a social artefact.

Following this Euro-centric culture, Atkinson, Stiglitz, Deaton and many others reminded us the relationship between consumer protection and competition law. They focused on 'consumer interest' with the common sensical premise that the consumers benefit from an honest competition in the long-run. Yet, today the debate is more relevant than ever because of three highly intricate reasons. First, honesty and trust are the moral foundations of the private legal regulations and they provide competition and consumer protection laws moral legitimacy. For example the moral nature of competition infringements manifests itself clearly where cartel offences are criminalised to increase deterrence or rather, change the modus of deterrence. ${ }^{31}$ Cartel offences create a "spiral of delinquency", whereby dishonesty, illicit planning and secretive implementation add a further layer. ${ }^{32}$ Ideally, honesty should be protected because it is seen as morally superior. In a discussion related to Sherman Act, Posner openly explained that the rule against price fixing had become a part of the law of conspiracy instead of the law of monopoly. ${ }^{33}$

Second, their clear effects demonstrate themselves in the economic realm. They are essential components of the neo-liberal market as they fuel the mechanism to function well in local and global levels. Today bona fides evolved into a general principle of European private law and it can be read through the lens of one microeconomic assumption: Honesty and trust is efficient. ${ }^{34}$ Any market requires a reasonable amount of information disclosed to its participants to function well. If the market provided perfect information, there would be no need for contractual good faith and its corrective functions. Market rules would easily replace moral norms that are translated into hard or soft law. Yet, real life markets contain market failures, and the corrective role of general principles become pivotal. Bona fides secures contractual freedom, saves contractual parties from additional costs of achieving honest and transparent information and protects their legitimate interests. It sustains the efficient co-operation in the society and limits the negative externalities. It decreases the transaction costs arising from the information asymmetry due to bounded rationality and opportunism, whereby it demonstrates the economic value of honesty and trust.

Last but not least, it is a question of social justice. It is about the inequalities of opportunity and the prohibition of exploitation of market power. ${ }^{35}$ The rationale of consumer law lies on the protection of the weaker party as a primarily moral concern with economic effects. The protection of the weaker party is a manifestation of keeping the contractual balance. On the other hand, providing

\footnotetext{
${ }^{31}$ MacCulloch (2007) at 355.

${ }^{32}$ Harding (2009) at 304.

${ }^{33}$ MacCulloch (2007) at 358.

${ }^{34}$ Hesselink (2011); Ucaryilmaz (2018).

${ }^{35}$ Bertola (2000), Deaton \& Muellbauer (1980) and Dixit \& Stiglitz (1977).
} 
contractual fairness is an effective way of sustaining social cooperation. ${ }^{36}$ 'Cooperation' being the key word, refers to the plurality of the actors and ties competition and consumer protection concerns together. Market failures that fall under the jurisdiction of competition law generally appear as compound problems. They are often joined with unfair contract terms or trade practices which are morally and ethically unjustifiable. ${ }^{37}$ As they are intertwined, the competition policy organically promotes the consumer welfare standard. As a reflection of ordoliberalism of Freiburg school, it creates a compromise between market structures and protection of the interests of small producers and consumers. ${ }^{38}$

The protection of honesty and trust in economic relations should not be understood as altruism. The opposite, market morality focuses on a reasonable level of honesty and protection of trust, as ideationally historical bona fides assumes a rivalry relationship. ${ }^{39}$ It assumes that human society consists of a series of market relations guided by the rationale of increasing the expected utility. Contractual relations are read through high transaction costs and legal rules aim to decrease the transaction costs, via protecting the legitimate expectations. In competitive markets the undertakings can prosper by surpassing their rivals in identifying and serving the consumer needs. Simply put, rivalry decreases the prices and increases the quality and hence, benefits the consumers as a group. Yet we should remember that it is not any type of rivalry that is beneficial for the consumers. Rather, the market and the economic society need honest rivalry. The European legal tradition as the essential core of the global legal paradigm is based on contractual freedom and cherishes the competition.

The modern consumer protection policy consists of preventing the sellers from increasing their sales by lying, giving incorrect information about their products or engaging in unfair practices. The economic reason behind this moral condemnation is the role of deceptive practices in creating negative externalities for the society. Such negative externalities created by acts of dolus are addressed from competition and consumer protection laws altogether since they not only affect the positions of honest competitors and consumer choice but also create consumer cynicism. ${ }^{40}$ The consumers are willing to give up short term material benefits such as price concerns for a fairer market. ${ }^{41}$ This also explains the success of corporate social responsibility initiatives like fair trade, rainforest alliance, Utz Kapeh or clean clothes campaign. As the contracts are ontologically incomplete and information is limited in a market setting, general principles with moral nature give the freedom and flexibility to the judges to apply the intrinsic value system they entail. ${ }^{42}$ This value system is essential for social justice concerns, when the justice at stake resonates not as mere equality but as equality of opportunity in the contemporary market society.

\footnotetext{
${ }^{36}$ Ducci \& Trebilcock (2019) at 84.

${ }^{37}$ Cseres (2013) at 13.

${ }^{38}$ Ducci \& Trebilcock (2019) at 94.

${ }^{39}$ Macpherson (1962).

${ }^{40}$ Leary (2005) 1150, fn 17.

${ }^{41}$ Graef, Clifford \& Valcke (2018) at 288.

${ }^{42}$ Mak (2012), Mak (2020).
} 


\section{Interdependencies of Competition and Consumer Protection}

Law and economics scholarship explains the goal of competition law as securing efficient allocation of resources. This means allocating them to whomever value those most, irrespective of how wealth is distributed among different stakeholder groups. ${ }^{43}$ Yet, competition law also seeks to prevent harm to the competition in general and as a consequence the consumer welfare is aimed to be maximised. ${ }^{44}$ In a competitive economy, the total consumer and producer rent being at the highest possible level is the goal of the policy makers. The interdependent nature of the relationship between competition and consumer protection first shows itself in their common ethos. They share a common character motivated by economic and moral reasons. Economically speaking, distorted competition generates distorted prices in the market. This may cause the consumers to have distorted incentives to choose the product that costs more than its actual worth. ${ }^{45}$ These webs of failures are the source of allocative inefficiency which disrupts distributive justice in the market society. This makes it possible to read the interdependencies through the light of the problem of economic justice.

The position of the consumer class in competition law is today stronger than ever. ${ }^{46}$ From a moral perspective, consumers are protected because they are assumed to be economically weaker in the contractual relationships compared to the producers or intermediaries. Because they do not have enough sectoral knowledge, they are easily manipulated and their interests are easily instrumentalised with profit-maximising concerns of the sellers. The emergence of the consuming class is a result of the evolution of the capitalist economies from a Weberian perspective. Yet, the protection of the weaker party is the basic mandate of the Roman bona fides when applied to the contemporary private relations. Throughout legal history this protection is provided by the standard of honesty as an essential requirement of the functioning of the market, as a component of the functioning social order. Consumers constitute one essential shareholder group in the competitive market paradigm as there cannot be a functioning competition without 'free' consumers. Consumer protection in the EU falls within the framework of the European competition policy that aims at prohibiting all market obstacles so that consumers can gain optimal benefit in the marketplace. ${ }^{47}$

Securing the competition in the market is a way of enhancing the consumer welfare. ${ }^{48}$ In other words, the pivotal role of consumer welfare in competition law is a question of social justice. Competition law condemns the horizontal agreements that hinder the consumers to benefit from the consumer surplus formed by the competitive price mechanism of the free market economy. To

\footnotetext{
${ }^{43}$ Cooter \& Ulen (2016) at 4 et seq.; Ducci \& Trebilcock (2019) at 84.

${ }^{44}$ Huffman (2010) at 13-14.

${ }^{45}$ Bar-Gill (2011) at 34.

${ }^{46}$ Hutchins \& Whelan (2006) at 182.

${ }^{47}$ See the Paris Summit of the EC, 19-21 October: 1972, .Gurkaynak (2004) at 24. About product safety and competition see Hilti AG v Commission Case C-53/92P, [1994] ECR I-667 and T-30/89 Eurofix Banco v. Hilti AG [1991] ECR II-1439. In these cases, the entities were not allowed to hide behind a consumer protection justification for product tying.

${ }^{48}$ Hutchins \& Whelan (2006) 182.
} 
illustrate, the TFEU art. 101 prohibits the horizontal agreements and concerted practices between the undertakings which actually or potentially distorts the competition such as price fixing, limiting the production or technical development, sharing markets or sources of supply, applying dissimilar conditions to equivalent transactions by creating competitive disadvantage and so on. Discriminating practices are strictly penalised under the EU law. ${ }^{49}$ Yet, the primary emphasis is not on the consumer welfare but on the free competition.

However if the agreement or concerted practice contributes to the new developments or techno-economic improvements and allows the consumers to get a share from the resulting benefit, the legal approach changes drastically. In such cases the competition authority is given the discretion to give an exemption to the rule as long as such practices or agreements do not induce a substantial restraint on the competition in the relevant market. ${ }^{50}$ Consumer welfare is therefore also a standard for the assessment of mergers and acquisitions. The mergers that efficiently combine using a cutting-edge technology with guaranteeing lower prices for the end-consumers are acceptable under the logic of competition law. ${ }^{51}$ Therefore the 'unwanted' horizontal agreements that may possibly benefit the consumer welfare are not prohibited per se but are generally assessed under the rule of reason analysis. ${ }^{52}$ The basic distinction of per se and rule of reason approaches coming from the American anti-trust discourse is based on a bona fide elaboration of the effects of anti-competitive practices. ${ }^{53}$

Nonetheless sometimes the dynamics of the market itself is an obstacle for the consumers. Competition law intervenes when such obstacles reaches to a level of mala fide exploitation. Art. 102 TFEU prohibits any abuse of a dominant position such as directly/indirectly imposing unfair prices or other unfair trading conditions, limiting production, markets or technical development to the prejudice of consumers and so on. The ratio legis of the article lies on the concept of 'abuse', referring to unreasonable and bad faith exploitation of a legitimately earned position. The abuse of a dominant position protects trust and honesty in relationships with unbalanced power dynamics. This is an illustration of how competition law mechanisms act as an agent of Roman bona fides and its correcting function. ${ }^{54}$ In parallel the first legislative controls on the terms of the consumer contracts was also based on the prohibition of abuse of rights/ imbalanced bargaining position. The excessive advantage attained to the detriment of the consumers creates the need to correct strictum ius. ${ }^{55}$ This is an example of how does the protection of honesty and trust with legal norms correct the market failures caused by incorrect-incomplete information and opportunism. ${ }^{56}$

\footnotetext{
${ }^{49}$ See the EU Commission Decision. 2000/12/EC and Commission Decision. IP/98/94.

${ }^{50}$ Haracoglou (2007) at 204. See the EU Commission Decision 1999/210/EC.

${ }^{51}$ Averitt \& Lande (2007) at 182; Weber (2005) at 633.

${ }^{52}$ About the rule of reason analysis in EU substantive law, see the Cassis de Dijon case. Rewe-

Zentral AG v Bundesmonopolverwaltung für Branntwein C-120/78), 1979:42,[1979]

${ }^{53}$ Kate \& Niels (2004) at 20.

${ }^{54}$ About the close relation between good faith and the doctrine of abuse of right see Whittaker (2019) at 409 and Hesselink (2011) at 641.

${ }^{55}$ Whittaker (2019) at 409.

${ }^{56}$ Mackaay (2012) at 161.
} 
Although the prohibition of the abuse of dominant position is directed at the imbalance between market actors, consumers are the essential component of the market dynamics. As such the consumer preferences are essential in evaluating the abuse. First, the dominant position is determined within the limits of the relevant product/service market, based on consumer preferences. Special characteristics of certain products or services affect the cross-price elasticity and therefore constitute a separate market for a special group of consumers. ${ }^{57}$ Enforcing consumer laws concerning advertising and marketing practices shape the understanding of how those relevant markets operate. Second, the consumer harm is essential in evaluating the level of exploitation. The abuse of a dominant position which does not directly restrict the competition in a relevant market is also prohibited in case it substantially harms the consumers. To illustrate, if the dominant undertaking in a relevant product market consciously stops the ReDe activities that would otherwise provide innovative efficiency to hinder new undertakings entering in the market, either by a concerted practice or a horizontal agreement, it will be held responsible by the competition authorities. The reason behind the idea is that consumers as the major stakeholder group in today's commercial society benefit from improved goods and services. The social aim of the protection of the consumers stems from the economic notion of innovative and allocative efficiency. ${ }^{58}$ Yet, its vitality and legal legitimacy comes from the idea of social justice.

The legal significance of honesty and trust in establishing patterns manifests itself mostly in the prohibition of exploitation. ${ }^{59}$ Competition regulation is aimed at reaching a balance between the market interests and moral values. ${ }^{60}$ Their interdependent relationship is primarily visible when deciding whether certain market conduct is considered to be anti-competitive or not. Honesty and trust are the primary normative criteria in evaluating the mala fide market behaviour whereby it is aimed to prevent the artificial distortions of the fair division of the joint market gains by exploitation. ${ }^{61}$ It is mistaken to assume that the distortion of competition per se harms the consumers or a conduct is anti-competitive because it is not consumer friendly. On the contrary, it is the distortion of the honest competition that harms the consumers. Consumer protection is a function in the equation of competition law. It sometimes manifests itself as the reason and sometimes as the result of the competition policies. Yet, morality gives its characteristics to the equation. ${ }^{62}$

Therefore de facto dominant position is not prohibited. The opposite, the competition is a process whereby actors compete to gain the most powerful market position by honest means. Competition policy prohibits the abuse of the dominant position because of the mala fide market conduct. Accepting otherwise would result with the competition authorities being merely price regulators. Similarly,

\footnotetext{
${ }^{57}$ United Brands v. Commission. C-27/76 [1978] ECR 207.

${ }^{58}$ Gurkaynak (2004) at 28.

${ }^{59}$ Ducci 7 Trebilcock (2019) at 88.

${ }^{60}$ MacCullough (2007) at 355.

${ }^{61}$ Mackaay (2012) at 171; Alexander (1962) at 148.

${ }^{62}$ Hutchins \& Whelan (2006) at 182.
} 
consumer protection is a direct application of the prohibition of exploitation and the protection of the weaker party in market relations. Another characteristic of the interdependent relationship between competition and consumer protection lies on their shared ethos as their inherent purpose. Honesty and trust sit in the middle of their ontology applicable to both competition and consumer protection. ${ }^{63}$

Their interdependencies are also supported by the institutional design. Lately, EU Member States started to integrate their consumer protection agencies to competition authorities. As Professor Cseres puts, consumer law protects the inner rules of commercial transactions while competition law concerns itself with the external effects. ${ }^{64}$ As they are closely interlinked from the perspective of the undisturbed application of contractual and property rights they often fall under each other's category and it is difficult to make a clear separation. Many consumer codes protect the economic order alongside with the consumers as a special group of stakeholders. This presents an example of strategic compliance to the good faith principle in consumer protection. Therefore, the adoption of separate consumer codes in national or supranational levels cannot be necessarily seen as the clear separation between consumer policy and competition law.

Consumer protection is necessary for the free market economy in the paradigm of neoclassical economics to provide a standard of social justice. Effective and institutional protection of honesty and trust is more important in commonplace contracts since they face a wide range of legal problems arising from the naivety of the parties to deceitful practices causing consumer misperception. Different bargaining positions of the parties emphasise the importance of the role of 'correction' as providing fairness among consumers, sellers and producers. ${ }^{65}$ This is applicable in competition and consumer protection in different scales. Consumer law protects in the micro-level individual transactions made by consumers as a stakeholder group in today's political ecology. But it also protects their decision making ability in the macro-level, which is an essential component of competition policy. ${ }^{66}$ The EU legislature constantly refers to the role of consumer law in building consumer confidence, as an integral part of competition. This highlights the importance of the protection of the consumer choice, as well as providing the necessary conditions to protect it.

\section{Consumer Choice as a Compromise}

Microeconomics provides us with the 'the consumer choice theory' that helps moving the idea of consumer confidence which is social by nature to a more 'scientific realm'. While competition law indirectly protects the consumers, it directly protects the consumer choice. The consumer choice theory assumes that

\footnotetext{
${ }^{63}$ In Ryan v. Sanders, the objective behavioural standard was determined as the standard of honesty for ordinary people. The court wanted to determine whether the "ordinary person" had a particular view of honesty. MacCulloch (2007) at 357.

${ }^{64}$ Cseres (2013).

${ }^{65}$ Ducci \& Trebilcock (2019) at 94.

${ }^{66}$ Van Loo (2019) at 215.
} 
the competition works efficiently if the consumers have a freedom to compare different products and their respective costs/benefits. Such freedom is sustained by providing reasonable information and the prohibition of exploitation. As such the theory emphasises the role of encouraging the suppliers to engage in honest, loyal and reasonable behaviour and hence, providing the consumers with the useful information about the prices and quality of the relevant products. This requires the prevention of false advertising and deceitful or non-verifiable information that may create disproportional advantages for certain market actors. Such information failures generated by practices of dolus eventually distort the market.

Competition law provides consumers with the choice of competing products and services, while consumer law allows the consumers to exercise that choice free from fraud, coercion, deception or demonstrably false information. An Expected economic benefits of honesty and trust imposes a disciplinary power as an external coercive force on each seller to satisfy the consumer interest. As a result, a well functioning competition creates the incentive to protect honesty and trust. It motivates the sellers to give accurate and useful information about their products and to fulfil their promises. The institutional protection of trust and honesty secures the market efficiency where the market incentives fail to promote them In parallel, the principle of good faith secures the ability of the consumers the ability to fairly negotiate the terms of the transaction whereby it protects them from entering into transactions that they would not enter if they knew the truth. As the ancient legal form of opportunism, dolus is the underlying motive behind the consumer choice. It explains why certain profit maximising competitive practices are prohibited such as the abuse of the dominant position.

The consumer choice theory highlights the synergies between the competition and the consumer protection. ${ }^{67}$ It assumes that the protection of honesty and trust has a pivotal role in providing social justice as it aims at the reduction of the total welfare cost. This requires competition and consumer protection to operate together to ensure the consumers to have the options and the ability to choose. With its focus on the observable demand patterns, it provides us with a fruitful standard of behaviour for the consumers with respect to preference relations and price systems. According to the consumer choice theory competition and consumer protection laws perform complementary tasks.

Ideally adopting 'consumer choice' as a standard in competition law may result with the direct increase of allocative efficiency and indirect increase of productive efficiency, since the cost savings result in lower prices for the consumers and the optimal distribution of goods is secured. In other words, the production continues until the marginal consumer benefit is equal to the marginal cost of production. Consumer choice standard is also well-suited to increase the innovation by encouraging technological and social improvements. It aims at providing options for the consumers in the short run, while ensuring the innovative efficiency in the relevant market in the long term. The consumer choice standard presupposes the idea of customer freedom, based on adequate knowledge about products and services. It requires the behavioural market failures such as consumer

${ }^{67}$ Averitt \& Lande (1997). See National Society of Professional Engineers v. US 435 US 679 (1978), Detroit Auto Dealers' Association 955 F.2d 457 (6 $6^{\text {th }}$ Cir.), cert. denied, 506 US 973 (1992). 
misperception to be minimised to be applicable. It also requires the inclusion of the societal benefits in the cost/benefit calculus. Therefore, it is suitable to be read through the lens of moral values of honesty and trust with which it is highly intertwined.

The evaluation of the societal benefits from the lens of morality sets the standard about which kind of innovations the policy maker prefers to encourage. For example, in today's data economies, corporate surveillance and transformation of the consumers into anonymous data banks are major concerns in consumer protection, and therefore should be carefully examined. The most recent example dealing with the relationship of competition law, consumer protection and privacy is the Facebook decision of the German Federal Competition Authority Bundeskartellamt. ${ }^{68}$ In 2019, Facebook was found in infringement of the German Competition Act (Gesetz gegen Wettbewerbsbeschränkungen) GWB due to the abuse of the dominant position in the private social network market by tying the services of the Facebook social network to the collection of the user related data by other services that are owned by Facebook itself such as WhatsApp and Instagram. The rationale of Bundeskartellamt was focused on the prohibition of exploitative practices to the detriment of consumers which are primarily referred as a contracting parties entering into an unbalanced negotiation. The Facebook decision is a milestone to understand the relationship among freedom, the prohibition of the abuse and privacy. ${ }^{69}$

The fundamental changes in information society changed the understanding of privacy and its narrative as a primary social and political issue. Yet, privacy has always been a societal good with a high social value. Reading competition and consumer protection from the same lens contributes in understanding the social costs of privacy infringement. Competition law uses the cost-benefit calculation as its assessment method. If the societal costs of the anti-competitive contracts are greater than the benefits of them, it is efficient not to enforce such contracts. ${ }^{70}$ Recent decisions support the idea that privacy having the 'high social value' is a component of consumer welfare and ergo, a parameter of competition in terms of product and service quality. ${ }^{71}$ Privacy as a social and political issue shed the economic value of societal phenomena in this calculus. This made it an integral part of the fairness/efficiency discussion, as well as demonstrated the role of noneconomic factors in the constitution of consumer welfare. The consumer choice theory has less econometric grounds than the pure efficiency or price models, which makes it more approachable to social theorists. It addresses the undervalued issues that are difficult to translate into terms of price. ${ }^{72}$

Protecting consumer choice revolves around the idea that both competition and consumer laws should shield the consumers from artificial constraints such as deception or dishonesty. Inefficient competition harms the society and the

\footnotetext{
${ }^{68}$ Facebook Decision, Bundeskartellamt, 6 February 2019, B6-22/16 at https://www.bundeskartella mt.de/SharedDocs/Entscheidung/DE/Entscheidungen/Missbrauchsaufsicht/2019/B6-22-16.html?n $\mathrm{n}=3591568$.

${ }^{69}$ Arendt (1998) at 38, Posner (2008), Averitt \& Lande (1997), and Cseres (2006) at 6.

${ }^{70}$ Cseres (2006) at 15.

${ }^{71}$ Reyna (2019) at 1-2.

${ }^{72}$ Averitt \&Lande (1997) at 178, 182.
} 
consumers as its extension. Inefficient consumer policy reinforces information asymmetries and behavioural biases, causing inefficient competition. ${ }^{73}$ The high information asymmetry in a market increases the search costs, diminishes the incentives to attain objective information and eventually distorts the decision making capacity of the consumers. The sellers have an incentive to exploit systematic biases and misperceptions to have maximum gain. ${ }^{74}$ The biased decisions of the consumers lead to allocative inefficiency. Therefore the market needs effective tools to increase the compliance to the ethical values such as honesty and trust to reconcile the social benefits of competition and consumer protection.

On the other hand, consumer law prohibits deceptive practices because they are immoral. Practices containing dolus are condemned because the moral blame of deception determines the outcome. Even in the US, many non-verifiable advertising cases are challenged on per se grounds by the Federal Trade Commission for this reason. ${ }^{75}$ Other unfair practices face a rule of reason analysis if they are prima facie not deceptive and the consumer harm is not reasonably avoidable. ${ }^{76}$ In this regard the 'consumer choice' perspective inflicts questions of consumer harm into competition law. This perspective does not require the number of consumer options to be maximised, but it does protect the types of options that are important to the consumers. ${ }^{77}$ Hereby, the non-price competition such as innovation, quality, privacy and safety play a major role especially when there is little price competition in highly regulated markets. Such product attributes and innovation are ways of focusing on expected future competition. ${ }^{78}$

Consumer choice theory prohibits the harmful conduct that significantly limits the range of choices that the free and honest market would normally provide for the consumers. Such harmful conduct generally manifests itself in tying or resale price maintenance that distort the clear decision making abilities of the consumers. ${ }^{79}$ Yet, certain market activities which may result in loss can still be permissible under the consumer choice approach only if their benefit to the consumers outweighs the costs. ${ }^{80}$ The choice standard protects not only the final "consumers" but all intermediary entities in the value chain. This creates another link between competition and consumer laws today as the boundaries between 'end customers' and 'producers' are disappearing.

The basic weakness of the theory is that it assumes the consumers to be capable of fully understanding their preferences and making rational comparisons between different goods and services to choose the best option for themselves within the paradigm of the competitive market. ${ }^{81}$ Overcharge or lowered quality

\footnotetext{
${ }^{73}$ Van Loo (2019) at 215, 219.

${ }^{74}$ Bar-Gill (2011) at 28.

${ }^{75}$ California Dental Associations v. Federal Trade Commission. 526 U.S. 756 (1999), Leary (2005) at 1148 .

${ }^{76}$ Leary (2005) at 1149.

${ }^{77}$ Averitt \& Lande (1997) at 182.

${ }^{78}$ Landman (1999) at 838, 850.

${ }^{79}$ Haracoglou (2007) at 197.

${ }^{80}$ Averitt \& Lande (1997) at 178.

${ }^{81}$ Reyna (2019) at 1.
} 
products are expected to result with the instant loss of consumers and require the market to self-regulate. It is assumed that when the consumers have adequate information that might affect their future choices, the information obtained can be reasonably understood by themselves. On the other hand, behavioural economics demonstrates that consumers are not necessarily rational actors and they are open to manipulation. Unlike the mercator prudens model that dominate the competition policy paradigm, the consumers have different levels of individual knowledge and sophistication. Yet, ignoring the model based on this criticism would be oversimplification of its goals. This does not require an essentialist view about the consumers being rational/irrational. Rather, what behavioural economics shows us is there is no objective homogeneous understanding of rationality in terms of human behaviour. Consumers are imperfectly rational. They are simultaneously rational and irrational, and this inescapably creates market failures and biased demand. The model of consumer choice requires the exogenous bias to be minimised.

From a competition policy perspective, limiting consumer choices creates additional anti-competitive effects in the society. ${ }^{82}$ The legal tools built upon the moral requirements of honesty and trust prevent the sellers from taking advantage of the lack of rationality of the consumers. Competition law guarantees that the biased options in the market are not diminished by external artificial restrictions such as price fixing or anti-competitive mergers. Consumer choice standard as its ancillary aims at consumer options to be as objective as possible. The moral nature of the duties arising from good faith (e.g. duty to inform, duty to protect, duty to cooperate etc.) shifts the focus on the emphasis on the micro-level harms to consumers to the macro-level implications such as privacy, environmental effects or gender inequalities. Honesty and trust are essential in consumer protection in the competition law narrative for two main reasons. First, they legitimise the prohibition of deceitful conduct that create exogenous bias. Second, they shield against social consumer harm which is not immediately visible in price and other output effects. ${ }^{83}$

Competition law prevents undertakings from the mala fide acquisitions or exploitations facilitated by their dominant positions. The dominant market power is perfectly legitimate if and only if it is the result of an honest, reasonable and loyal competition. On the other hand, the consumer choice theory has a different focus. It assumes that the bad faith market power can be used to create negative effects on the price, quality and variety choices in a particular market to the detriment of the quality and quantity of the consumer decisions. Yet, two focal points complete each other. In other words, the consumer choice standard should not be reduced to a mere arithmetic of consumer options. In case of a legitimately attained dominant market position, the consumer welfare will not be in danger although the consumer choice would be limited from a quantitative perspective. Rather, the consumer choice standard should be seen from a social justice

\footnotetext{
${ }^{82}$ United States v. Dentsply, 399 F.3d 181, 194 (3d Cir. 2005).

${ }^{83}$ As noted by the Director General of the European Commission's competition department, Johannes Laitenberger. Reyna (2019) at 2. The proof of actual consumer harm is not required because it is inferred from injury. Houck (2001) at 596.
} 
perspective whereby its protection within the framework of the contractual relationships is based on an ethical competition policy raising consumer awareness. It is open to dispute whether the consumer choice paradigm should be explicitly introduced in national competition policies. ${ }^{84}$ Nonetheless, contemplating its role will help the competition authorities to re-evaluate the possible tools of consumer protection and its relation to social justice.

\section{Conclusion}

The abandonment of the normativity of moral theories in economics is as old as its perception as a positive science. Yet, the economic order in the market is regulated by legislative tools which provide legal normativity whereby laying down rules of just market conduct. As such, this paper concerns itself with two specific examples and their economic relation to morality: Competition and consumer protection laws, and their interdependencies. Both competition and consumer laws deal with the distortions in the market, yet with different enforcement methods and different target groups. They both aim at providing fairness in the current economic paradigm but their moral roots are often ignored. This article proposes to read competition and consumer protection through the lens of European legal culture. The protection of honesty and trust in consumer protection and competition reminds us the moral perspectives that once pushed to periphery.

Competition law is concerned with the competitive process, and a healthy and unimpaired competitive process is presumed to be in the consumer interest. ${ }^{85}$ Consumer benefits are essential in deciding on the scale of harm to competition, as well as on the exemptions for anticompetitive behaviour. In other words, consumer detriment legitimises the prohibition of permitted conduct. ${ }^{86}$ From a teleological perspective, it is not disputable whether or not competition policy in general is directed to consumer protection. Rather the question is whether consumer protection is a primary or a secondary concern. ${ }^{87}$ The role of morality sits in the middle of this discussion. As John Vickers puts, competition and consumer protection policies 'work together in tandem if not as one'.88 This is well illustrated in the consumer choice standard which might operate as a bridge between consumer protection and competition policies. It aims at innovative, productive and allocative efficiency, as well as creating potential Pareto improvements in economy. ${ }^{89}$ Whereby to do this, it emphasises the role of information provided to consumers as an essential part of competition and emphasises the place of honesty as transparency in the competition regulation.

\footnotetext{
${ }^{84}$ About its contemporary impact on EU competition policy see Behrens (2014) at 5.

${ }^{85}$ Fishman v. Estate of Wirtz, 807 F2d 520, 536 (7th Cir. 1986).

${ }^{86}$ Haracoglou (2007) at 197.

${ }^{87}$ Leary (2005) at 1148 .

${ }^{88}$ John Vickers, Opening remarks to the European Competition and Consumer day, 15 September

2005 at www.oft.gov.uk.; Haracoglou (2007) at 177.

${ }^{89}$ Stavins, Wagner \& Gernot (2003).
} 
The requirement of disclosure of reasonable information and the prohibition of exploitation are the two major implications of translating the moral values of honesty and trust into the legal/economic realm. The aim is to provide an Aristotelian balance in contractual relationships between different market actors. The tendency towards social cooperation reminds us the historical role of honesty and trust, and from their perspective we witness competition and consumer laws as two sides of a coin. This also contributes in understanding their key role in case of non-price competition. The effect of sustainability and corporate social responsibility is increasingly becoming a major core in this legal regime, juxtaposing consumer protection and competition. In the future we will witness more consumer friendly markets which revolve around a fair competition policy, where efficiency and fairness go hand in hand to provide the 'social solidarity'. The complementary nature of competition and consumer protection from a moral point of view is necessary to be remembered when confronting the need to create a well-balanced social justice system that is also extended to the economic justice.

\section{References}

Alexander, G. (1962). 'Honesty and Competition: Some Competitive Virtues in the False Naming of Goods' in Santa Clarita Law Review 31:141-160.

Arendt, H. (1998). The Human Condition. Chicago: University of Chicago Press.

Aristotle, Nicomachean Ethics (translated and introduced by Sir W.D. Ross, 2009) London: Oxford University Press.

Averitt. N.W. \& R.H. Lande (1997). 'Consumer Sovereignty: A Unified Theory of Antitrust and Consumer Protection Law' in Antitrust Law Journal 65:713-753.

Bar-Gill, O. (2011). 'Competition and Consumer Protection: A Behavioral Economics Account' in NYU Law and Economics Research Paper Series:11-42.

Behrens, P. (2014). 'The "consumer choice" paradigm in German ordoliberalism and its impact Upon EU competition Law', Discussion Papers 1/14, Europa-Kolleg Hamburg, Institute for European Integration.

Bertola, G. (2000). 'Macroeconomics of Distribution and Growth' in A. Atkinson \& F. Bourgignon (eds) The Handbook of Income Distribution, Vol. 1. 477-540. Amsterdam: Elsevier.

Chroust, A.H. (1942). 'Aristotle's Conception of Equity (Epieikeia)' in Notre Dame Law Review 18(2):119-128.

Cseres, K.J. (2006). 'The Impact of Consumer Protection on Competition and Competition Law: The case of Deregulated Markets'. Amsterdam Center for Law \& Economics, Working Paper No. 2006-05.

Cseres, K.J. (2011). 'Contract law and competition law' in A.S. Hartkamp, E.H. Hondius, M.W. Hesselink, C. Mak \& C.E. du Perron (eds), Towards a European Civil Code, 4th ed. 205-238. The Hague: Kluwer Law.

Cseres, K.J. (2013). 'Integrated or Separate: Institutional Design for the Enforcement of Competition Law and Consumer Law'. Amsterdam Centre for European Law and Governance Working Paper Series, no. 1.

Cohen, G.M. (1992). 'The Negligence- Opportunism Trade-off in Contract Law' in Hofstra Law Review 20(4):941-1016.

Collins, H. (2012). 'Cosmopolitanism and Transnational Private Law' in European Review of Contract Law 8(3):311-325. 
Cooter, R. \& T. Ulen (2016). Law and Economics, 6th ed. Berkley: Berkley Law Books, 4 ff.

Deaton, A. \& J. Muellbauer (1980). Economics and Consumer Behavior, Cambridge: Cambridge University Press.

Dixit, A. \& J. Stiglitz (1977). 'Monopolistic Competition and Optimum Product Diversity' in American Economic Review 67(3):297-308.

Ducci, F. \& M. Trebilcock (2019). 'The Revival of Fairness Discourse in Competition Policy' in The Antitrust Bulletin 64(1):79-104.

Durkheim, É. (1973) (ed. by R.N. Bellah). On Morality and Society. Chicago: University of Chicago Press.

Gurkaynak, G. (2004). Turk Rekabet Uygulaması Icin Hukuk ve Iktisat Perspektifinden Amac Tartismasi. Ankara: Rekabet Kurumu.

Hart H.L.A. (1994). The Concept of Law.2nd ed. Oxford: Oxford University Press.

Haracoglou, I. (2007). 'Competition Law, Consumer Policy and the Retail Sector: The Systems' Relation and the Effects of a Strengthened Consumer Protection Policy on Competition Law' in Competition Law Review 3(2):175-208.

Harding, C. (2009). "Capturing the Cartel's Friends: Cartel Facilitation and the Idea of Joint Criminal Enterprise" in European Law Review 34 (2):298-309.

Hayek, F. (1978). Law, Legislation and Liberty, The Mirage of Social Justice. Chicago: University of Chicago Press.

Hesselink, M.W. (2011). 'The Concept of Good Faith', in A.Sa Hartkamp, M.W. Hesselink, E.H. Hondius, C. Mak \& C. E. du Perron (eds), Towards a European Civil Code. 619-649. Alphen aan den Rijn: Kluwer Law International.

Honore, T. (2002). 'The Necessary Connection between Law and Morality' in Oxford Journal of Legal Studies 22 (3):489-495.

Houck, S. (2001). 'Injury to Competition/Consumers in High Tech Cases' in St. John's Law Review 75: 593-614.

Huffman M (2010). 'Bridging the Divide: Theories for Integrating Competition Law and Consumer Protection' in European Competition Journal 6 (1):7-25.

Graef, I., Clifford, D. \& P. Valcke (2018). 'Fairness and Enforcement: Bridging Competition, Data Protection and Consumer Law' in International Data Privacy Law 8:200-223.

Kate, A. \& G. Niels (2004). 'Introduction: Antitrust in the U.S and the EU Converging or Diverging Paths?' in The Antitrust Bulletin 49 (1-2):1-27.

Landman, L.B. (1999) Innovation and the Structure of Competition: Future Markets in European and American Law. Patent. \& Trademark Office Society.

Leary, T.B. (2005). 'Competition Law and Consumer Protection Law: Two Wings of the Same House' in Antitrust Law Journal 72 (3) 1147-1151.

MacCulloch, A. (2007). 'Honesty, Morality and Cartel Offence' in European Competition Law Review 28(6):355-363.

Macpherson, C.B. (1962). The Political Theory of Possessive Individualism: From Hobbes to Locke. Oxford: Clarendon.

Mak, C. (2007). 'Harmonising Effects of Fundamental Rights in European Contract Law' in Erasmus Law Review 1(1):59-80.

Mak, C. (2012). Europe-building through private law. Lessons from Constitutional Theory' in European Review of Competition Law 3:326-341.

Mak, C. (2020). 'Civil Courts as Constitutional Courts: Polity-building Through Private Law in Europe' in European Review of Private Law 4:953-972.

Mattei, U. (1994). 'Efficiency as Equity: Insights from Comparative Law and Economics' in Hastings International and Comparative Law Review 18 (3):57-173. 
Muris, T.J. (2005). 'Principles for a Successful Competition Agency' in The University of Chicago Law Review, 72:165-187.

Posner, R.A. (2008). 'Privacy, Surveillance, and Law' in The University of Chicago Law Review 75(1):245-260.

Reyna, A. (2019). 'The Shaping of a European Consumer Welfare Standard for the Digital Age' in Journal of European Competition Law \& Practice 10 (1):1-2.

Schiller, A.A. (1930). 'Trade Secrets and the Roman Law; The Actio Servi Corrupti' in Columbia Law Review, 30(6):837-884.

Stavins, R., Wagner, A. \& C. Wagner (2003). 'Interpreting Sustainability in Economic Terms: Dynamic Efficiency Plus Intergenerational Equity' in Economic Letters 79(3):339-343.

Study Group of Social Justice of European Private Law (2004). 'Social Justice in European Contract Law: A Manifesto' in European Law Journal 10(6):663-674.

Summers, R.S. (1982). 'The Duty of Good Faith: Its Recognition and Conceptualization' in Cornell Law Review 67(4):810-841.

Ucaryilmaz, T. (2020). 'The Principle of Good Faith in Public International Law' in Deusto Law Journal 68(1):43-59.

Van Loo, R. (2019). 'Broadening Consumer Law: Competition, Protection, and Distribution' in Notre Dame Law Review 95(1):211-262.

Weber, S.W. (2005). 'In Search of Economic Justice: Considering Competition and Consumer Protection Law' in Chicago Law Journal 36:631-639.

Whittaker, S. (2019). 'Unfair Terms in Commercial Contracts and the Two Laws of Competition: French Law and English Law Contrasted' in Oxford Journal of Legal Studies 39(2):404-434.

Williamson, O.E. (1975). Markets and Hierarchies: Analysis and Antitrust Implications. New York, Free Press.

Williamson, O.E. (1985). The Economic Institutions of Capitalism-Firms, Markets, Relational Contracting, New York, Free Press.

Winkel, L. (2010). 'Forms of Imposed Protection in Legal History, Especially in Roman Law' in Erasmus Law Review 3(2):154-162. 
